\title{
Tank 41H Salt-Well Sample Analysis
}

by

\author{
C. J. Martino
}

Westinghouse Savannah River Company

Savannah River Site

Aiken, South Carolina 29808

This paper was prepared in connection with work done under the above contract number with the U.S.

Department of Energy. By acceptance of this paper, the publisher and/or recipient acknowledges the U.S.

Government's right to retain a nonexclusive, royalty-free license in and to any copyright covering this paper, along with the right to reproduce and to authorize others to reproduce all or part of the copyrighted paper. 
This document was prepared in conjunction with work accomplished under Contract No. DE-AC09-96SR18500 with the U. S. Department of Energy.

\section{DISCLAIMER}

This report was prepared as an account of work sponsored by an agency of the United States Government. Neither the United States Government nor any agency thereof, nor any of their employees, makes any warranty, express or implied, or assumes any legal liability or responsibility for the accuracy, completeness, or usefulness of any information, apparatus, product or process disclosed, or represents that its use would not infringe privately owned rights. Reference herein to any specific commercial product, process or service by trade name, trademark, manufacturer, or otherwise does not necessarily constitute or imply its endorsement, recommendation, or favoring by the United States Government or any agency thereof. The views and opinions of authors expressed herein do not necessarily state or reflect those of the United States Government or any agency thereof.

This report has been reproduced directly from the best available copy.

Available for sale to the public, in paper, from: U.S. Department of Commerce, National Technical Information Service, 5285 Port Royal Road, Springfield, VA 22161, phone: (800) 553-6847, fax: (703) 605-6900

email: orders@ntis.fedworld.gov

online ordering: http://www.ntis.gov/help/index.asp

Available electronically at http://www.osti.gov/bridge

Available for a processing fee to U.S. Department of Energy and its contractors, in paper, from: U.S. Department of Energy, Office of Scientific and Technical Information, P.O. Box 62, Oak Ridge, TN 37831-0062,

phone: (865)576-8401,

fax: (865)576-5728

email: $\underline{\text { reports@ adonis.osti.gov }}$ 
Keywords: Tank Farm

Criticality

Salt Dissolution

Low Curie Salt

Waste Removal

Retention: Permanent

\section{Tank 41H Salt-Well Sample Analysis}

C. J. Martino

Publication date: August 15, 2002

Westinghouse

Savannah River Company

Aiken, SC 29808

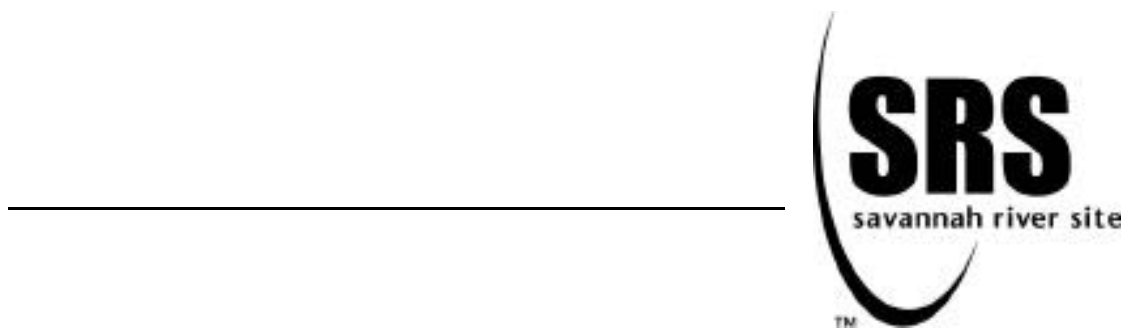


WSRC-TR-2002-00343

Revision 0

Authors:

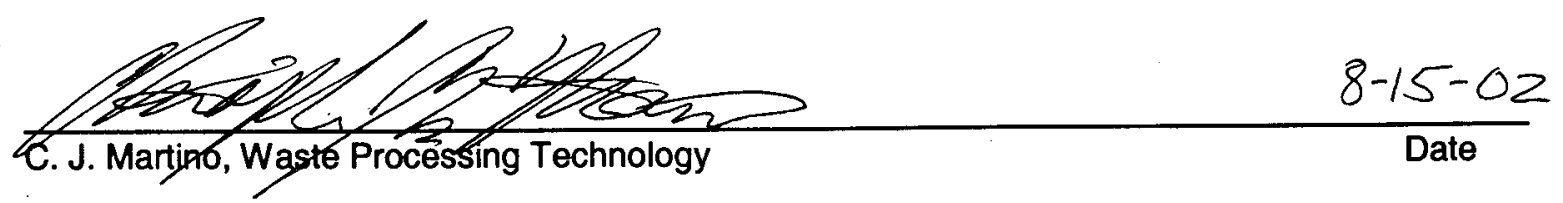

Design Check:

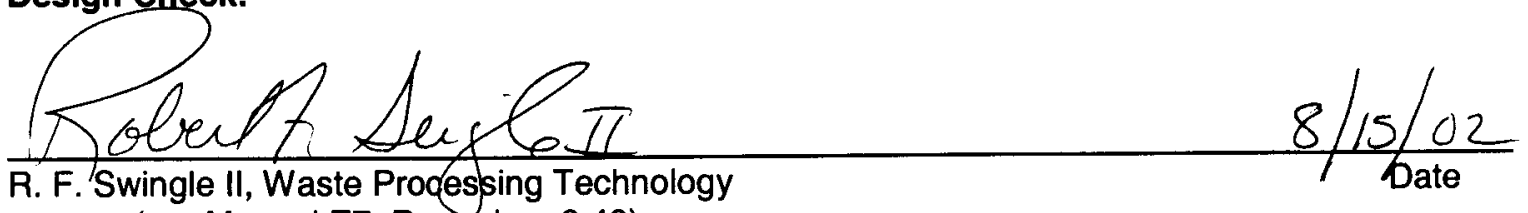
(per Manual E7, Procedure 2.40)

Approvals/Review:

$\frac{\text { V.B. Van Pelt }}{\text { W. B. Van Pelt, Manager, Waste Processing Technology }} \frac{8-16-02}{\text { Date }}$

$\frac{\text { W. W. Market for E. A- Treed per telecon }}{\text { E. J. Freed, Manager, concentration, Storage, \& Transfer Engineering }}$

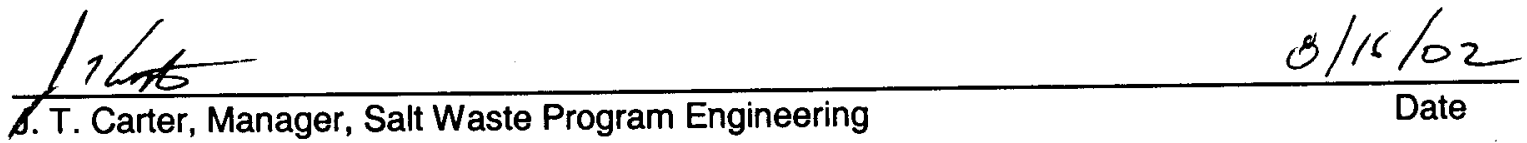

$\frac{\text { W.B. Van feet for W.L.Tonosailis per telecon 8-16-02 }}{\text { W. L. Tamosaitis, Manager, Waste Processing Technology }}$

Page ii 


\section{Summary}

This report provides results of the analysis of the Tank $41 \mathrm{H}$ salt-well criticality sample TK-41-HTF-E173. Statistics are provided for the analyses of the wet as-received salt and the solids insoluble in multiple strikes of excess inhibited water. The dried insoluble solids comprise $0.22 \mathrm{wt}$. \% of the wet as-received sample and contain approximately $0.2 \mathrm{wt}$. \% uranium with a ${ }^{235} \mathrm{U}$ enrichment of $12.6 \%$. The bulk of the insoluble solid material (84.4 wt. \%) is best represented by $\mathrm{Al}_{2} \mathrm{O}_{3}{ }^{*} 3 \mathrm{H}_{2} \mathrm{O}$, which is gibbsite or its polymorph bayerite. 


\section{Table of Contents}

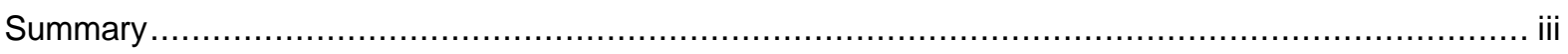

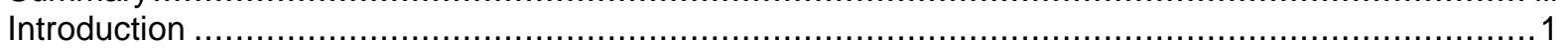

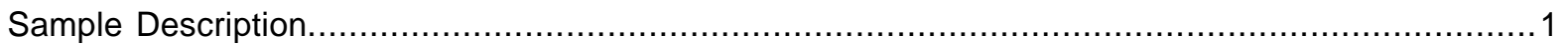

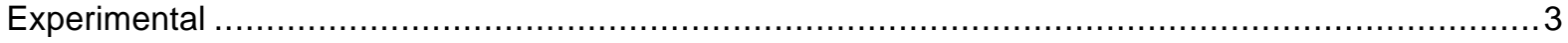

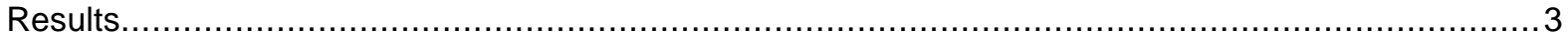

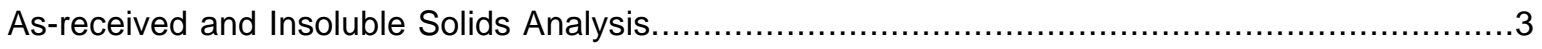

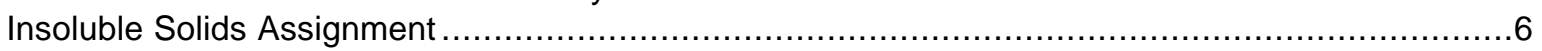

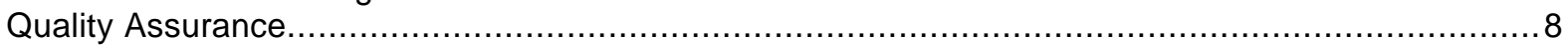

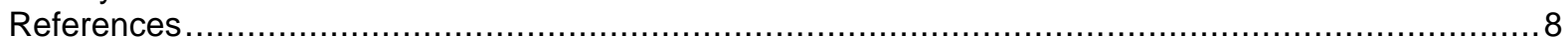

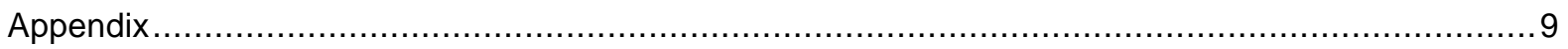




\section{List of Figures}

Figure 1: Bottom (outside of retaining fingers) of Sampler \#1 (TK-41-HTF-E-173, left) and Sampler \#2 (TK-41-HTF-E-174, right).

Figure 2: Appearance of the Tank $41 \mathrm{H}$ salt sample fractions......

\section{List of Tables}

Table 1: Tank $41 \mathrm{H}$ salt-well criticality sample details.

Table 2: Summary of the analytical results of the wet as-received Tank $41 \mathrm{H}$ salt sample (TK-41-HTF-

E-173).

Table 3: Summary of the analytical results of the dry insoluble solids from the Tank $41 \mathrm{H}$ salt sample

(TK-41-HTF-E-173).

Table 4: Mass balance of components assigned to Tank $41 \mathrm{H}$ insoluble solids, based on sample TK-

41-HTF-E-173.

Table 5: TK-41-HTF-E-173 wet as-received sample ICP-ES results.

Table 6: TK-41-HTF-E-173 wet as-received sample actinides results. .................................... 10

Table 7: TK-41-HTF-E-173 dry insoluble solids ICP-ES results..........................................11

Table 8: TK-41-HTF-E-173 dry insoluble solids actinides results......................................... 12

\section{Abbreviations}

C.I. Confidence Interval

N/A Not Applicable

n.d. Not determined 


\section{Introduction}

The High Level Waste (HLW) division plans to dissolve at least 100,000 gallons of salt in Tank $41 \mathrm{H}$ for use as a feed to the Low Curie Salt process. ${ }^{1}$ The planned dissolution and removal methods are not covered by the existing Nuclear Criticality Safety Evaluation (NCSE) for Tank $41 \mathrm{H}$. This sample analysis provides results to support the NCSE needed to qualify the entire contents of the tank for dissolution and removal.

Prior to sampling, HLW removed the supernate from the surface of Tank $41 \mathrm{H}$ and transferred it to the $3 \mathrm{H}$-Evaporator system. On May 11, 2002, HLW completed mining a salt-well from the Tank $41 \mathrm{H}$ saltcake surface ( $351 ")$ to within $24 "$ of the tank bottom. The solids that remained in the newly mined hole were allowed to settle for about three weeks, after which time two core samples were pulled from near the bottom of this hole.

HLW requested that the Savannah River Technology Center (SRTC) perform Sample-Plan Suite 1 (Salt Criticality Characterization) on the Tank $41 \mathrm{H}$ saltcake samples in support of the criticality evaluation $^{2}$. The Task Technical and Quality Assurance Plan documents the planned sample analysis. ${ }^{3}$ SRTC analyzed the as-received sample and the washed insoluble solids for uranium and plutonium isotopes and neutron poisons. This analysis covers one of the two samples received (TK41-HTF-E-173).

\section{Sample Description}

On June 4, 2002, HLW obtained two samples of salt from Tank $41 \mathrm{H}$. On the first attempt to use Sampler \#1, the sampler moved easily into and down the well and stopped at 132". The mast was disconnected from the crane and pounded to a sample depth of 96", where it stopped. When the sampler was brought out of the tank, the indicator revealed that the sampler was empty. During a second attempt to use Sampler \#1, the sampler moved easily into and down the salt-well and stopped well past 96", and was subsequently pounded to 20". The indicator revealed that Sampler \#1 was full. Sampler \#2 moved easily into and down the well on the first attempt, stopped at 36", and was subsequently pounded to 6". The indicator revealed that Sampler \#2 was full. ${ }^{4}$

Table 1: Tank $41 \mathrm{H}$ salt-well criticality sample details.

\begin{tabular}{|c|c|c|c|l|}
\hline $\begin{array}{c}\text { Sample } \\
\text { Jar \# }\end{array}$ & $\begin{array}{c}\text { Sampler \# } \\
\text { (and fraction) }\end{array}$ & Tank Farm ID\# & Weight (g) & \multicolumn{1}{|c|}{ Description } \\
\hline 1 & 1 & TK-41-HTF-E-173 & 153.8 & $\begin{array}{l}\text { Overall homogeneity throughout } \\
\text { sampler. White/off-white with a } \\
\text { few darker specks. }\end{array}$ \\
\hline 2 & 2 dark & TK-41-HTF-E-174 & 64.5 & $\begin{array}{l}\text { From lower portion of sampler, } \\
\text { primarily outside of retaining } \\
\text { basket. Darker and wetter than } \\
\text { Sample Jars \#1 and \#3. Slushy } \\
\text { with an orange/brown color. } \\
\text { Consistent with the appearance } \\
\text { of a salt slurry containing sludge. }\end{array}$ \\
\hline 3 & 2 light & TK-41-HTF-E-174 & 80.2 & $\begin{array}{l}\text { From the top portion of the } \\
\text { sampler, packed inside of the } \\
\text { retaining basket. Similar } \\
\text { appearance to Sample Jar \#1, } \\
\text { slightly wetter. }\end{array}$ \\
\hline
\end{tabular}


The two Tank $41 \mathrm{H}$ salt-well core samples arrived at SRTC and were placed in the shielded cells on June 5 and were opened on June 6 . Table 1 outlines the description of the two samples as they were placed into three glass jars. Both sample vials were essentially full (see Figure 1), containing portions of salt both inside and outside of the retaining basket. Sampler \#1 contained 153.8 grams of salt that appeared similar throughout the vial. Sampler \#2 contained 144.7 grams of material that exhibited two fractions of different appearance. The interface between the two fractions was not distinct, but was approximately at the sampler retaining fingers. The material in the upper portion of Sampler \#2 (inside of the retaining fingers and packed into the cap) resembled the material from Sampler \#1. The material in the lower portion of Sampler \#2 (outside of the retaining fingers) appeared darker and wetter than the material from Sampler \#1 and the upper portion of Sampler \#2. These "light" and "dark" fractions of TK-41-HTF-E-174 were placed in separate sample jars (Jar \#3 and \#2, respectively) so that a decision could be made as to what portions of the sample to analyze. The samples, including the dark portions, looked lighter than expected based on the appearance of the recent Tank $37 \mathrm{H}$ salt-well core sample. ${ }^{5}$
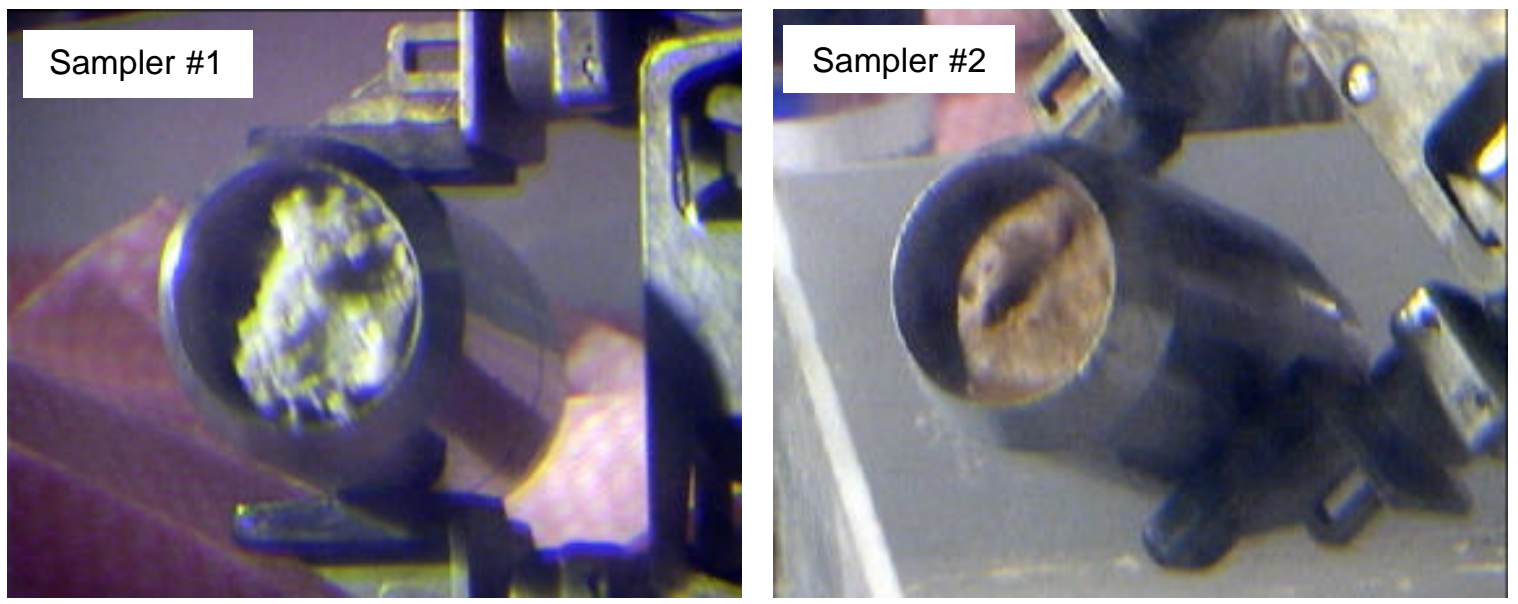

Figure 1: Bottom (outside of retaining fingers) of Sampler \#1 (TK-41-HTF-E-173, left) and Sampler \#2 (TK-41-HTF-E-174, right).
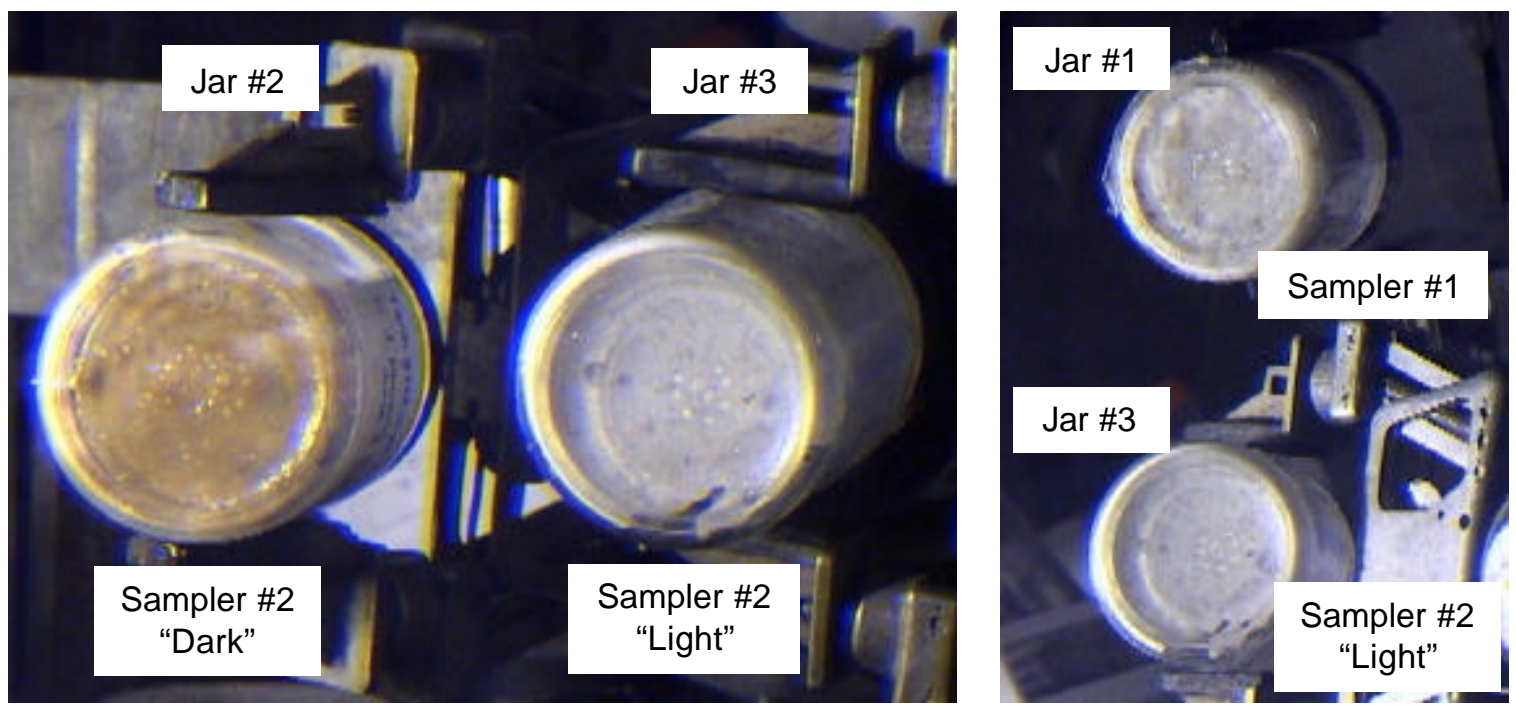

Figure 2: Appearance of the Tank $41 \mathrm{H}$ salt sample fractions. 


\section{Experimental}

The saltcake material from only Sampler \#1 (TK-41-HTF-E-173) was homogenized and characterized for uranium and plutonium isotopes and potential neutron poisons. Portions of the as-received sample were digested by two methods and characterized in triplicate. The remainder of the salt from Sampler \#1 was washed three times with inhibited water, resulting in insoluble solids that were dried, digested by two methods, and characterized in duplicate. The following are the details of this general procedure.

Three aliquots of the as-received sample were pulled for aqua regia dissolution and three were pulled for sodium peroxide fusion dissolution. Approximately $0.5 \mathrm{~g}$ of original sample material was dissolved into $250 \mathrm{~mL}$ of liquid. The dissolved samples were removed from the shielded cells and transferred to the Analytical Development Section (ADS) for analysis for actinides and neutron poisons. Analyses conducted include inductively coupled plasma-emission spectrometry (ICP-ES) for various elemental species including neutron poisons, inductively coupled plasma-mass spectrometry (ICP-MS) for various actinide isotopes, and PuTTA (Pu-238/241) analysis for ${ }^{238} \mathrm{Pu}$ and ${ }^{241} \mathrm{Pu}$. Additional analyses were requested to satisfy requirements for the drain disposal of waste.

Prior to digesting the aliquots with sodium peroxide, those samples were dried to a constant weight at $115 \pm 10^{\circ} \mathrm{C}$. (The sodium peroxide reacts with water before the digestion is completed. Drying is not necessary for samples dissolved using aqua regia.) This drying step allowed a measurement of the weight fraction total solids in the sample.

The insoluble solids preparation process uses a conservatively large amount of wash-water (roughly 3 washes with a 3:1 ratio of inhibited water to original salt for each wash) when compared with in-tank dissolution processes. The insoluble solids were separated from the salt cake sample by washing portions of the salt in four polypropylene centrifuge tubes. Each tube was filled with a 10-g aliquot of the as-received sample and washed three times with $30 \mathrm{~g}$ of inhibited water $(0.0158 \mathrm{M} \mathrm{NaOH})$ to dissolve the soluble material. After each wash, the samples were centrifuged to minimize the solids volume and the clear supernate was decanted. The density of the as-received salt was estimated by noting the displacement of the $10 \mathrm{~g}$ of salt during the first addition of $30 \mathrm{~g}$ of inhibited water. After the last of the three washes, not enough solids remained in the four tubes to allow for adequate analysis. An additional $13 \mathrm{~g}$ of salt was added to each tube and washed once with $40 \mathrm{~g}$ of inhibited water. The remainder of the sample in Jar \#1 was processed by the addition of $10 \mathrm{~g}$ of salt to each tube and washing three times with $40 \mathrm{~g}$ of inhibited water. The resulting insoluble solids, when dried, was an amount of material adequate for duplicate analysis of the two dissolution methods.

After the final wash, the insoluble solids in each of the tubes were dried at $60^{\circ} \mathrm{C}$. The solids were transferred into polytetrafluoroethylene beakers and dried to a constant weight at $115 \pm 10^{\circ} \mathrm{C}$. Two aliquots each of the dried solids were then dissolved using aqua regia and sodium peroxide fusion digestion. Approximately $0.07 \mathrm{~g}$ of dried insoluble solids was dissolved into $100 \mathrm{~mL}$ of liquid in each of the dissolutions. The dried insoluble solids were submitted for the same analyses as the asreceived sample aliquots.

\section{Results}

\section{As-received and Insoluble Solids Analysis}

The wet as-received salt sample TK-41-HTF-E-173 had a specific gravity of 1.9 (95\% C.I. of \pm 0.2$)$ and a total solids content of $83.5 \mathrm{wt}$. $\%$ (95\% C.I. of $\pm 9.3 \mathrm{wt}$. \%). After the washing process was complete, $1.14 \mathrm{~g}$ of wet insoluble solids was obtained. In all, $131.3 \mathrm{~g}$ of the wet as-received sample 
was consumed in the washing process, yielding $0.291 \mathrm{~g}$ of dry insoluble solids. Thus, the dry insoluble solids comprised 0.22 wt. \% of the wet as-received sample.

Table 2 and Table 3 contain the summaries of the analytical results for the wet as-received sample and the dried insoluble solids, respectively. Data from the individual dissolutions used to calculate the statistics reported in Table 2 and Table 3 are contained in the appendix (see Table 5 and Table 6 for the as-received results and Table 7 and Table 8 for the insoluble solids results).

Results from ICP-ES, ICP-MS, and Pu-238/241 are given in weight percentage. The as-received sample results are reported on a wet basis and the insoluble solids results are reported on a dry basis. Sodium values are not reported for peroxide fusion digestions because of the sodium content of the sample is small in relation to that in the added sodium peroxide. It is evident that significant zinc is introduced during peroxide fusion digestion. Aqua regia dissolution is a poor method for the dissolution of silicon, and thus no silicon values are reported for aqua regia of the insoluble solids. A combined average of the three (for as-received sample) or two (for insoluble solids) determinations for each of the two digestion methods is reported. Values that are below detection limits are signified by "<", and averages for replicates that contain a mixture of actual values and below detection limit values are signified by " ". In addition to the analytical results reported by ADS, several calculated values are given: total uranium, total plutonium, and ${ }^{235} \mathrm{U} /$ total uranium. The Pu-238/241 method did not routinely lead to the mass quantification of ${ }^{239} \mathrm{Pu}$ and ${ }^{240} \mathrm{Pu}$, so the Total $\mathrm{Pu}$ value may be low in instances where ICP-MS did not measure ${ }^{239} \mathrm{Pu}$ and ${ }^{240} \mathrm{Pu}$ above the minimum detection limits.

Table 2 and Table 3 contain several statistics: the average of the determinations $(\bar{x})$, the standard deviation of the determinations (s), and the one- and two-sided $95 \%$ confidence intervals (C.I.) for the sample average. The reported standard deviations capture a combination of the variance in the composition of the salt sample and the variance from analytical uncertainties. These standard deviations are used to calculate the $95 \%$ C.I. about the average by the following equation:

$$
\text { C.I. }=t_{\alpha, n-1} \frac{s}{\sqrt{n}}
$$

where $t$ is Student's $t$-statistic, $n$ is the number of determinations, and $\alpha$ is the tail probability $(0.025$ for the two-sided $95 \%$ C.I. and 0.05 for the one-sided $95 \%$ C.I.). This can be used to bound the true average value, $\mu$ with $95 \%$ confidence. As more replicate analyses are performed, this confidence interval on the true average value decreases even if the standard deviation remains the same, due to the influence of the increase in $n$ and the reduction in the $t$-statistic.

The two-sided confidence interval should be used in cases where you want to bound the average between two numbers with $95 \%$ confidence (i.e., $\mu=\bar{x} \pm 95 \%$ C.I.). For example, it may be important to know that the ${ }^{235} \mathrm{U}$ enrichment in the insoluble solids was found to be $0.126 \pm 0.005$ with $95 \%$ confidence. The one-sided confidence interval should be used to assure that the average is above or below a specific value with $95 \%$ confidence (i.e., $\mu>\bar{x}-95 \%$ C.I. or $\mu<\bar{x}+95 \%$ C.I.). For instance, it also may be important to know that aluminum comprises at least $29.6-1.59 \mathrm{wt}$ \% (or 28.0 wt. \%) of the insoluble solids with $95 \%$ confidence. This approach for calculating the confidence interval assumes that the determined quantities of each analyte are normally distributed about the true average quantity. These confidence intervals are valid for the tank sample analyzed. 
Table 2: Summary of the analytical results of the wet as-received Tank $41 \mathrm{H}$ salt sample (TK-41HTF-E-173).

\begin{tabular}{|c|c|c|c|c|}
\hline Species/Analysis & $\begin{array}{l}\text { Sample } \\
\text { Average }\end{array}$ & $\begin{array}{l}\text { Sample } \\
\text { Std Dev. }\end{array}$ & $\begin{array}{l}\text { 2-sided } \\
95 \% \text { C.I. }\end{array}$ & $\begin{array}{l}\text { 1-sided } \\
95 \% \text { C.I. }\end{array}$ \\
\hline \multicolumn{5}{|c|}{ ICP-ES (wt. \%) } \\
\hline Al & $2.76 \mathrm{E}+00$ & 2.88E-01 & 3.02E-01 & 2.37E-01 \\
\hline $\mathrm{Cr}$ & 8.88E-03 & $6.49 E-03$ & 8.06E-03 & 6.19E-03 \\
\hline $\mathrm{Cu}$ & 7.76E-03 & 2.99E-03 & $3.14 \mathrm{E}-03$ & $2.46 \mathrm{E}-03$ \\
\hline $\mathrm{Fe}$ & $1.35 \mathrm{E}-02$ & $1.38 \mathrm{E}-02$ & $1.72 \mathrm{E}-02$ & $1.32 \mathrm{E}-02$ \\
\hline $\mathrm{Na}$ & $2.49 \mathrm{E}+01$ & $1.15 \mathrm{E}-01$ & 2.87E-01 & $1.95 \mathrm{E}-01$ \\
\hline$P$ & 3.64E-02 & 8.46E-03 & 1.05E-03 & 8.06E-03 \\
\hline \multicolumn{5}{|c|}{ ICP-MS (wt. \%) } \\
\hline $\mathrm{M}-235(\mathrm{U})$ & $1.12 \mathrm{E}-04$ & 2.04E-05 & 2.14E-05 & $1.68 \mathrm{E}-05$ \\
\hline $\mathrm{M}-238(\mathrm{U}, \mathrm{Pu})$ & $1.02 \mathrm{E}-03$ & 3.88E-04 & 4.07E-04 & 3.19E-04 \\
\hline \multicolumn{5}{|c|}{ Pu-238/241 (wt. \%) } \\
\hline${ }^{238} \mathrm{Pu}$ & $9.33 \mathrm{E}-07$ & 1.62E-07 & $1.70 \mathrm{E}-07$ & 1.34E-07 \\
\hline${ }^{241} \mathrm{Pu}$ & $7.08 \mathrm{E}-08$ & 2.67E-08 & $2.81 \mathrm{E}-08$ & $2.20 \mathrm{E}-08$ \\
\hline \multicolumn{5}{|c|}{ Actinides Summary (wt. \%) } \\
\hline Total U & 1.16E-03 & 3.68E-04 & 3.86E-04 & 3.03E-04 \\
\hline Total Pu & $1.00 \mathrm{E}-06$ & $1.49 \mathrm{E}-07$ & 1.57E-07 & 1.23E-07 \\
\hline \multicolumn{5}{|c|}{ Enrichment (mass fraction) } \\
\hline${ }^{235} \mathrm{U} /$ Tot.U & 0.104 & 0.032 & 0.033 & 0.026 \\
\hline
\end{tabular}


Table 3: Summary of the analytical results of the dry insoluble solids from the Tank 41H salt sample (TK-41-HTF-E-173).

\begin{tabular}{|c|c|c|c|c|}
\hline Species/Analysis & $\begin{array}{l}\text { Sample } \\
\text { Average }\end{array}$ & $\begin{array}{l}\text { Sample } \\
\text { Std Dev. }\end{array}$ & $\begin{array}{l}\text { 2-sided } \\
95 \% \text { C.I. }\end{array}$ & $\begin{array}{l}\text { 1-sided } \\
95 \% \text { C.I. }\end{array}$ \\
\hline \multicolumn{5}{|c|}{ ICP-ES (wt. \%) } \\
\hline $\mathrm{Al}$ & $2.96 \mathrm{E}+01$ & $1.35 \mathrm{E}+00$ & $2.15 E+00$ & $1.59 \mathrm{E}+00$ \\
\hline $\mathrm{Ba}$ & 3.76E-02 & 9.37E-03 & $1.49 \mathrm{E}-02$ & $1.10 \mathrm{E}-02$ \\
\hline $\mathrm{Ca}$ & 7.34E-01 & $1.67 \mathrm{E}-01$ & $2.66 \mathrm{E}-01$ & $1.96 \mathrm{E}-01$ \\
\hline $\mathrm{Cr}$ & $1.14 \mathrm{E}+00$ & 4.24E-01 & $6.75 \mathrm{E}-01$ & 4.99E-01 \\
\hline $\mathrm{Cu}$ & 7.76E-02 & 5.47E-02 & 8.71E-02 & $6.44 \mathrm{E}-02$ \\
\hline $\mathrm{Fe}$ & $2.78 \mathrm{E}+00$ & $1.71 \mathrm{E}+00$ & $2.72 \mathrm{E}+00$ & $2.01 \mathrm{E}+00$ \\
\hline $\mathrm{Mn}$ & $1.08 \mathrm{E}-01$ & $4.61 \mathrm{E}-02$ & 7.33E-02 & $5.42 \mathrm{E}-02$ \\
\hline $\mathrm{Na}$ & 7.20E-01 & $1.98 \mathrm{E}-02$ & $1.78 \mathrm{E}-01$ & 8.84E-02 \\
\hline $\mathrm{Ni}$ & $7.50 \mathrm{E}-02$ & $2.67 \mathrm{E}-02$ & $4.25 \mathrm{E}-02$ & $3.14 \mathrm{E}-02$ \\
\hline $\mathrm{Si}$ & $4.13 \mathrm{E}-01$ & 7.71E-02 & $6.92 \mathrm{E}-01$ & $3.44 \mathrm{E}-01$ \\
\hline $\mathrm{Sr}$ & $1.36 \mathrm{E}-01$ & 4.06E-02 & $6.46 \mathrm{E}-02$ & $4.78 \mathrm{E}-02$ \\
\hline $\mathrm{Zn}$ & 8.73E-02 & $1.94 \mathrm{E}-02$ & $1.75 \mathrm{E}-01$ & 8.68E-02 \\
\hline \multicolumn{5}{|c|}{ ICP-MS (wt. \%) } \\
\hline M-232 (Th, U) & $1.79 \mathrm{E}-03$ & $2.58 E-04$ & 2.32E-03 & $1.15 \mathrm{E}-03$ \\
\hline $\mathrm{M}-233(\mathrm{U})$ & 1.35E-03 & 4.60E-04 & 7.32E-04 & 5.41E-04 \\
\hline $\mathrm{M}-234(\mathrm{U})$ & 7.30E-03 & $2.70 \mathrm{E}-03$ & 4.30E-03 & $3.18 \mathrm{E}-03$ \\
\hline M-235 (U) & 2.17E-02 & 8.02E-03 & $1.28 \mathrm{E}-02$ & 9.44E-03 \\
\hline $\mathrm{M}-236(\mathrm{U})$ & 7.95E-03 & 2.77E-03 & 4.41E-03 & $3.26 \mathrm{E}-03$ \\
\hline M-237 (Np) & $6.44 \mathrm{E}-03$ & 2.31E-03 & 3.67E-03 & 2.71E-03 \\
\hline $\mathrm{M}-238(\mathrm{U}, \mathrm{Pu})$ & $1.34 \mathrm{E}-01$ & 4.91E-02 & 7.81E-02 & $5.78 \mathrm{E}-02$ \\
\hline $\mathrm{M}-239(\mathrm{Pu})$ & 4.42E-04 & 一 & 一 & - \\
\hline \multicolumn{5}{|c|}{ Pu-238/241 (wt. \%) } \\
\hline${ }^{238} \mathrm{Pu}$ & 2.05E-04 & 8.61E-05 & 1.37E-04 & $1.01 \mathrm{E}-04$ \\
\hline${ }^{241} \mathrm{Pu}$ & $1.14 \mathrm{E}-06$ & $6.54 \mathrm{E}-07$ & $1.04 \mathrm{E}-06$ & 7.69E-07 \\
\hline \multicolumn{5}{|c|}{ Actinides Summary (wt. \%) } \\
\hline Total U & $1.72 \mathrm{E}-01$ & 6.30E-02 & $1.00 \mathrm{E}-01$ & 7.41E-02 \\
\hline Total Pu & $6.54 \mathrm{E}-04$ & 4.91E-04 & 7.81E-04 & 5.78E-04 \\
\hline \multicolumn{5}{|c|}{ Enrichment (mass fraction) } \\
\hline${ }^{235} \mathrm{U} /$ Tot.U & 0.126 & 0.003 & 0.005 & 0.004 \\
\hline
\end{tabular}

$\underline{\text { Insoluble Solids Assignment }}$

As evident from Table 3 , the insoluble solids in the Tank $41 \mathrm{H}$ sample consist primarily of aluminum compounds, with the additional presence of calcium, iron, chromium, and other trace compounds. What follows is an assignment discreet compounds to the elemental analysis in order to perform a mass balance for the insoluble solids. The assignment of the compounds is based on previously reported characterization of SRS and Hanford sludge solids as well as solids isolated after multiple 
contacts with inhibited water. ${ }^{6}$ The insoluble solids were prepared by drying at $115^{\circ} \mathrm{C}$, which would remove the free water but retain the waters of hydration. For simplicity, all elements present in quantities $<0.1 \mathrm{wt}$. \% were not included in the mass balance analysis.

The silicon is assumed to be present as sodium aluminosilicate, $\mathrm{Na}_{8} \mathrm{Al}_{6} \mathrm{Si}_{6} \mathrm{O}_{24}\left(\mathrm{NO}_{3}\right)_{2}{ }^{*} 4 \mathrm{H}_{2} \mathrm{O}$. This aluminosilicate compound requires a small portion of the total aluminum present, and the bulk of the aluminum is assigned as $\mathrm{Al}_{2} \mathrm{O}_{3}{ }^{*} 3 \mathrm{H}_{2} \mathrm{O}$ (also written $\mathrm{Al}(\mathrm{OH})_{3}$ ). This aluminum hydroxide phase is either gibbsite or its polymorph, bayerite. The remainder of the solids assignments does not have a major impact on the overall mass balance. The iron is assigned as goethite, $\mathrm{Fe}_{2} \mathrm{O}_{3}{ }^{*} \mathrm{H}_{2} \mathrm{O}$, the calcium as $\mathrm{CaCO}_{3}$, the manganese as $\mathrm{Mn}_{2} \mathrm{O}_{3}$, the chromium as $\mathrm{Cr}_{2} \mathrm{O}_{3}{ }^{*} \mathrm{H}_{2} \mathrm{O}$, the uranium as $\mathrm{Na}_{2} \mathrm{U}_{2} \mathrm{O}_{7}$, and the strontium as $\mathrm{SrCO}_{3}$. The excess sodium is assigned as sodium sulfate decahydrate. As seen in Table 4, the solids from this assignment sum to 97.6 wt. \% (nearly 100 wt. $\%$ ). This lends validation to the assignments of the major insoluble components, namely $\mathrm{Al}_{2} \mathrm{O}_{3}$ * $3 \mathrm{H}_{2} \mathrm{O}$. Based on this composition, the waters of hydration represent $30.0 \mathrm{wt} \%$ of the solids (excluding the contribution from the presumed $\mathrm{Na}_{2} \mathrm{SO}_{4}{ }^{*} 10 \mathrm{H}_{2} \mathrm{O}$ ).

Aluminum is the major metallic component of the insoluble solids. If a less hydrated form of alumina is substituted in this analysis for gibbsite or bayerite (e.g., boehmite $-\mathrm{Al}_{2} \mathrm{O}_{3}{ }^{*} \mathrm{H}_{2} \mathrm{O}$ or $\mathrm{AIOOH}$ ), the mass balance does not close. The assignment of aluminum as boehmite yields to only $64.9 \mathrm{wt}$ \% boehmite and a sum of the solid masses of only $78.1 \mathrm{wt} . \%$. In addition, the selection of gibbsite or bayerite is consistent with the production and storage conditions for the saltcake in Tank $41 \mathrm{H}$. Generally, higher temperatures $\left(>100^{\circ} \mathrm{C}\right.$ for long periods of time) are required to convert gibbsite and bayerite into boehmite.

Table 4: Mass balance of components assigned to Tank $41 \mathrm{H}$ insoluble solids, based on sample TK-41-HTF-E-173.

\begin{tabular}{|c|c|c|}
\hline Assigned Solid & $\mathrm{mol} / 100 \mathrm{~g}$ & wt. \% \\
\hline $\mathrm{Al}_{2} \mathrm{O}_{3} * 3 \mathrm{H}_{2} \mathrm{O}$ & 0.541 & 84.4 \\
\hline $\mathrm{Na}_{8} \mathrm{Al}_{6} \mathrm{Si}_{6} \mathrm{O}_{24}\left(\mathrm{NO}_{3}\right)_{2}{ }^{*} 4 \mathrm{H}_{2} \mathrm{O}$ & 0.00245 & 2.68 \\
\hline $\mathrm{Cr}_{2} \mathrm{O}_{3} * \mathrm{H}_{2} \mathrm{O}$ & 0.0109 & 1.86 \\
\hline $\mathrm{Fe}_{2} \mathrm{O}_{3}{ }^{*} \mathrm{H}_{2} \mathrm{O}$ & 0.0249 & 4.43 \\
\hline $\mathrm{Mn}_{2} \mathrm{O}_{3}$ & 0.000981 & 0.155 \\
\hline $\mathrm{Na}_{2} \mathrm{U}_{2} \mathrm{O}_{7}$ & 0.000362 & 0.230 \\
\hline $\mathrm{CaCO}_{3}$ & 0.0183 & 1.83 \\
\hline $\mathrm{SrCO}_{3}$ & 0.00155 & 0.229 \\
\hline $\mathrm{Na}_{2} \mathrm{SO}_{4} * 10 \mathrm{H}_{2} \mathrm{O}$ & 0.00551 & 1.77 \\
\hline Total: & & 97.6 \\
\hline
\end{tabular}

The 84.4 wt. \% value for $\mathrm{Al}_{2} \mathrm{O}_{3}{ }^{*} 3 \mathrm{H}_{2} \mathrm{O}$ is the best estimate based on the sample average, but conservative lower-end value for gibbsite or bayerite has been requested. If the one-sided $95 \%$ confidence interval is subtracted from the average, the insoluble solids were shown to contain $>28.0$ wt. \% aluminum. This corresponds an amount of gibbsite and/or bayerite in the insoluble solids of $>79.8 \mathrm{wt} \%$. 


\section{Quality Assurance}

This work satisfies the requirements of the original task technical and quality assurance plan. Laboratory Notebooks WSRC-NB-2002-00088 and WSRC-NB-2002-00128 contain the experimental data. Personnel in ADS and SCO keep additional notebooks containing this data.

\section{References}

${ }^{1}$ L. B. Romanowski, "Low Curie Salt Processing Technical Plan," HLW-SDT-2002-00031, Rev. 0, March 2002.

2 J. R. Sessions, "NCSA Sample Analysis for Tank 41," HLE-TTR-2002-099, Rev. 0, April 30, 2002.

${ }^{3}$ C. J. Martino, "Task Technical and Quality Assurance Plan for the Characterization of the Tank $41 \mathrm{H}$ Salt-Well Core Sample," WSRC-RP-2002-00306, Rev.0, May 29, 2002.

${ }^{4}$ J. R. Sessions, personal communication, June 4, 2002.

${ }^{5}$ R. F. Swingle, "Results of Analyses of Tank 37H Criticality Salt Samples (HTK-493 and 494)," WSRC-TR-2002-00244, Rev. 0, May 29, 2002.

${ }^{6}$ D. T. Hobbs, "Composition of Tank 41H Insoluble Solids," SRT-LWP-2002-00068, July 18, 2002. 


\section{Appendix}

Table 5: TK-41-HTF-E-173 wet as-received sample ICP-ES results.

\begin{tabular}{|c|c|c|c|c|c|c|c|c|}
\hline & \multicolumn{4}{|c|}{ Aqua Regia Dissolution } & \multicolumn{4}{|c|}{ Peroxide Fusion Digestion } \\
\hline Species/Analysis & 1 & 2 & 3 & Average & 1 & 2 & 3 & Average \\
\hline \multicolumn{9}{|c|}{ ICP-ES (wt. \%) } \\
\hline $\mathrm{Ag}$ & $<2.67 \mathrm{E}-03$ & $<4.51 \mathrm{E}-03$ & $<3.29 \mathrm{E}-03$ & $<3.49 \mathrm{E}-03$ & $\mathrm{~N} / \mathrm{A}$ & $\mathrm{N} / \mathrm{A}$ & $\mathrm{N} / \mathrm{A}$ & N/A \\
\hline $\mathrm{Al}$ & $2.79 \mathrm{E}+00$ & $2.29 E+00$ & $3.02 \mathrm{E}+00$ & $2.70 \mathrm{E}+00$ & $3.07 \mathrm{E}+00$ & $2.79 \mathrm{E}+00$ & $2.59 \mathrm{E}+00$ & $2.82 \mathrm{E}+00$ \\
\hline$B$ & $<9.35 \mathrm{E}-03$ & $<1.58 \mathrm{E}-02$ & $<1.15 \mathrm{E}-02$ & $<1.22 \mathrm{E}-02$ & $<6.25 \mathrm{E}-03$ & $<7.50 \mathrm{E}-03$ & $<6.07 \mathrm{E}-03$ & $<6.61 \mathrm{E}-03$ \\
\hline $\mathrm{Ba}$ & $<6.34 \mathrm{E}-03$ & $<1.07 \mathrm{E}-02$ & $<7.83 \mathrm{E}-03$ & $<8.29 \mathrm{E}-03$ & $<4.24 \mathrm{E}-03$ & $<5.09 \mathrm{E}-03$ & $<4.12 \mathrm{E}-03$ & $<4.48 \mathrm{E}-03$ \\
\hline $\mathrm{Ca}$ & $<7.68 \mathrm{E}-03$ & $<1.30 \mathrm{E}-02$ & $<9.47 \mathrm{E}-03$ & $<1.01 \mathrm{E}-02$ & 3.80E-02 & $4.26 \mathrm{E}-02$ & $3.48 \mathrm{E}-02$ & 3.85E-02 \\
\hline $\mathrm{Cd}$ & $<1.40 \mathrm{E}-03$ & $<2.37 \mathrm{E}-03$ & $<1.73 \mathrm{E}-03$ & $<1.83 \mathrm{E}-03$ & $<9.38 \mathrm{E}-04$ & $<1.13 \mathrm{E}-03$ & $<9.10 \mathrm{E}-04$ & $<9.93 E-04$ \\
\hline $\mathrm{Cr}$ & 7.42E-03 & $<3.39 \mathrm{E}-03$ & $3.26 \mathrm{E}-03$ & 4.69E-03 & $2.10 \mathrm{E}-02$ & 8.94E-03 & 9.29E-03 & 1.31E-02 \\
\hline $\mathrm{Cu}$ & $8.05 E-03$ & 1.30E-02 & $8.75 E-03$ & 9.93E-03 & $6.38 \mathrm{E}-03$ & $5.98 \mathrm{E}-03$ & $4.41 \mathrm{E}-03$ & 5.59E-03 \\
\hline $\mathrm{Fe}$ & 7.46E-03 & $<2.03 \mathrm{E}-03$ & 4.97E-03 & 4.82E-03 & 3.95E-02 & 1.78E-02 & $9.15 \mathrm{E}-03$ & 2.22E-02 \\
\hline$\overline{\mathrm{Gd}}$ & $<7.81 \mathrm{E}-03$ & $<1.32 \mathrm{E}-02$ & $<9.64 \mathrm{E}-03$ & $<1.02 \mathrm{E}-02$ & $<5.22 \mathrm{E}-03$ & $<6.27 \mathrm{E}-03$ & $<5.07 \mathrm{E}-03$ & $<5.52 E-03$ \\
\hline $\bar{K}$ & $<3.13 \mathrm{E}-01$ & $<5.29 \mathrm{E}-01$ & $<3.86 \mathrm{E}-01$ & $<4.09 \mathrm{E}-01$ & $<2.09 \mathrm{E}-01$ & $<2.51 \mathrm{E}-01$ & $<2.03 \mathrm{E}-01$ & $<2.21 \mathrm{E}-01$ \\
\hline$\overline{\mathrm{La}}$ & $<2.40 \mathrm{E}-03$ & $<4.06 \mathrm{E}-03$ & $<2.97 \mathrm{E}-03$ & $<3.14 \mathrm{E}-03$ & $<1.61 \mathrm{E}-03$ & $<1.93 \mathrm{E}-03$ & $<1.56 \mathrm{E}-03$ & $<1.70$ E-03 \\
\hline $\mathrm{Li}$ & $<1.44 \mathrm{E}-02$ & $<2.43 \mathrm{E}-02$ & $<1.77 \mathrm{E}-02$ & $<1.88 \mathrm{E}-02$ & $<9.60$ E-03 & $<1.15 \mathrm{E}-02$ & $<$ <9.32E-03 & $<1.01 \mathrm{E}-02$ \\
\hline $\mathrm{Mg}$ & $<1.77 \mathrm{E}-03$ & $<2.99 \mathrm{E}-03$ & $<2.18 \mathrm{E}-03$ & $<2.31 \mathrm{E}-03$ & $<1.18 \mathrm{E}-03$ & $<1.42 \mathrm{E}-03$ & $<1.15 \mathrm{E}-03$ & $<1.25 \mathrm{E}-03$ \\
\hline $\mathrm{Mn}$ & $<2.67 \mathrm{E}-04$ & $<4.51 \mathrm{E}-04$ & $<3.29 \mathrm{E}-04$ & $<3.49 \mathrm{E}-04$ & $<1.79 \mathrm{E}-04$ & $<2.14 \mathrm{E}-04$ & $<1.73 \mathrm{E}-04$ & $<1.89 \mathrm{E}-04$ \\
\hline Mo & $<1.77 \mathrm{E}-02$ & $<2.99 \mathrm{E}-02$ & $<2.18 \mathrm{E}-02$ & $<2.31 \mathrm{E}-02$ & $<1.18 \mathrm{E}-02$ & $<1.42 \mathrm{E}-02$ & $<1.15 \mathrm{E}-02$ & $<1.25 \mathrm{E}-02$ \\
\hline $\mathrm{Na}$ & $2.50 \mathrm{E}+01$ & $2.48 \mathrm{E}+01$ & $2.48 \mathrm{E}+01$ & $2.49 \mathrm{E}+01$ & $\mathrm{~N} / \mathrm{A}$ & $\mathrm{N} / \mathrm{A}$ & $\mathrm{N} / \mathrm{A}$ & N/A \\
\hline $\mathrm{Ni}$ & $<4.51 \mathrm{E}-03$ & $<7.62 \mathrm{E}-03$ & $<5.56 \mathrm{E}-03$ & $<5.90$ E-03 & 5.04E-03 & $<3.62$ E-03 & $<2.92 \mathrm{E}-03$ & 3.86E-03 \\
\hline$P$ & 2.86E-02 & $<3.89 \mathrm{E}-02$ & 3.38E-02 & $3.38 \mathrm{E}-02$ & 4.98E-02 & 4.04E-02 & 2.70E-02 & $3.91 \mathrm{E}-02$ \\
\hline $\mathrm{Pb}$ & $<1.06 \mathrm{E}-02$ & $<1.80 \mathrm{E}-02$ & $<1.31 \mathrm{E}-02$ & $<1.39 \mathrm{E}-02$ & $<7.12 \mathrm{E}-03$ & $<8.55 \mathrm{E}-03$ & $<6.91 \mathrm{E}-03$ & $<7.53 \mathrm{E}-03$ \\
\hline $\mathrm{Sb}$ & $<1.26 \mathrm{E}-01$ & $<2.13 \mathrm{E}-01$ & $<1.56 \mathrm{E}-01$ & $<1.65 \mathrm{E}-01$ & n.d. & n.d. & n.d. & n.d. \\
\hline $\mathrm{Si}$ & $<5.57 \mathrm{E}-03$ & $<9.42 \mathrm{E}-03$ & $<6.88 \mathrm{E}-03$ & $<7.29 \mathrm{E}-03$ & $<3.73 \mathrm{E}-03$ & $<4.47 \mathrm{E}-03$ & $<3.62 \mathrm{E}-03$ & $<3.94 \mathrm{E}-03$ \\
\hline Sn & $<1.50 \mathrm{E}-02$ & $<2.54 \mathrm{E}-02$ & $<1.85 \mathrm{E}-02$ & $<1.96 \mathrm{E}-02$ & $<1.00 \mathrm{E}-02$ & $<1.21 \mathrm{E}-02$ & $<9.75 \mathrm{E}-03$ & $<1.06 \mathrm{E}-02$ \\
\hline $\mathrm{Sr}$ & $<2.54 \mathrm{E}-03$ & $<4.29 \mathrm{E}-03$ & $<3.13 \mathrm{E}-03$ & $<3.32 \mathrm{E}-03$ & $6.44 \mathrm{E}-03$ & $7.27 \mathrm{E}-03$ & $6.22 \mathrm{E}-03$ & $6.64 \mathrm{E}-03$ \\
\hline $\mathrm{Ti}$ & $<2.57 \mathrm{E}-03$ & $<4.35 \mathrm{E}-03$ & $<3.17 \mathrm{E}-03$ & $<3.36 \mathrm{E}-03$ & $<1.72 \mathrm{E}-03$ & $<2.06 \mathrm{E}-03$ & $<1.67 \mathrm{E}-03$ & $<1.82 \mathrm{E}-03$ \\
\hline $\mathrm{Zn}$ & $<1.07 \mathrm{E}-03$ & $<1.81 \mathrm{E}-03$ & $<1.32 \mathrm{E}-03$ & $<1.40 \mathrm{E}-03$ & $\mathrm{~N} / \mathrm{A}$ & $\mathrm{N} / \mathrm{A}$ & $\mathrm{N} / \mathrm{A}$ & N/A \\
\hline $\mathrm{Zr}$ & $<7.61 \mathrm{E}-03$ & $<1.29 \mathrm{E}-02$ & $<9.39 \mathrm{E}-03$ & $<9.97 \mathrm{E}-03$ & $\mathrm{~N} / \mathrm{A}$ & $\mathrm{N} / \mathrm{A}$ & $\mathrm{N} / \mathrm{A}$ & N/A \\
\hline
\end{tabular}


Table 6: TK-41-HTF-E-173 wet as-received sample actinides results.

\begin{tabular}{|c|c|c|c|c|c|c|c|c|}
\hline & \multicolumn{4}{|c|}{ Aqua Regia Dissolution } & \multicolumn{4}{|c|}{ Peroxide Fusion Digestion } \\
\hline Species/Analysis & 1 & 2 & 3 & Average & 1 & 2 & 3 & Average \\
\hline \multicolumn{9}{|c|}{ ICP-MS (wt. \%) } \\
\hline M-230 (Th) & $<3.17 \mathrm{E}-05$ & $<5.36 \mathrm{E}-05$ & $<3.91 \mathrm{E}-05$ & $<4.15 \mathrm{E}-05$ & $<5.36 \mathrm{E}-05$ & $<6.43 \mathrm{E}-05$ & $<5.20 \mathrm{E}-05$ & $<5.66 \mathrm{E}-05$ \\
\hline $\mathrm{M}-231(\mathrm{~Pa})$ & $<3.17 \mathrm{E}-05$ & $<5.36 \mathrm{E}-05$ & $<3.91 \mathrm{E}-05$ & $<4.15 \mathrm{E}-05$ & $<5.36 \mathrm{E}-05$ & $<6.43 \mathrm{E}-05$ & $<5.20 \mathrm{E}-05$ & $<5.66 \mathrm{E}-05$ \\
\hline M-232 (Th,U) & $6.20 \mathrm{E}-05$ & $<5.36 \mathrm{E}-05$ & $<3.91 \mathrm{E}-05$ & 5.16E-05 & $<5.36 \mathrm{E}-05$ & $<6.43 \mathrm{E}-05$ & $<5.20 \mathrm{E}-05$ & $<5.66 \mathrm{E}-05$ \\
\hline $\mathrm{M}-233(\mathrm{U})$ & $<3.17 \mathrm{E}-05$ & $<5.36 \mathrm{E}-05$ & $<3.91 \mathrm{E}-05$ & $<4.15 \mathrm{E}-05$ & $<5.36 \mathrm{E}-05$ & $<6.43 \mathrm{E}-05$ & $<5.20 \mathrm{E}-05$ & $<5.66 \mathrm{E}-05$ \\
\hline $\mathrm{M}-234(\mathrm{U})$ & 5.30E-05 & $<5.36 \mathrm{E}-05$ & 4.60E-05 & 5.09E-05 & $<5.36 \mathrm{E}-05$ & $<6.43 \mathrm{E}-05$ & $<5.20 \mathrm{E}-05$ & $<5.66 \mathrm{E}-05$ \\
\hline M-235 (U) & $1.39 \mathrm{E}-04$ & $1.02 \mathrm{E}-04$ & $9.40 \mathrm{E}-05$ & 1.12E-04 & $1.20 \mathrm{E}-04$ & 8.80E-05 & $1.29 \mathrm{E}-04$ & 1.12E-04 \\
\hline M-236 (U) & 4.20E-05 & $<5.36 \mathrm{E}-05$ & $4.40 \mathrm{E}-05$ & 4.65E-05 & $<5.36 \mathrm{E}-05$ & $<6.43 \mathrm{E}-05$ & $<5.20 \mathrm{E}-05$ & $<5.66 \mathrm{E}-05$ \\
\hline M-237 (Np) & 4.60E-05 & $<5.36$ E-05 & $<3.91 \mathrm{E}-05$ & 4.62E-05 & $<5.36 \mathrm{E}-05$ & $<6.43 \mathrm{E}-05$ & $<5.20 \mathrm{E}-05$ & $<5.66$ E-05 \\
\hline $\mathrm{M}-238(\mathrm{U}, \mathrm{Pu})$ & 9.63E-04 & 8.64E-04 & 7.74E-04 & 8.67E-04 & $9.19 \mathrm{E}-04$ & 1.79E-03 & $7.79 \mathrm{E}-04$ & 1.16E-03 \\
\hline M-239 (Pu) & $<3.17 \mathrm{E}-05$ & $<5.36 \mathrm{E}-05$ & $<3.91 \mathrm{E}-05$ & $<4.15 \mathrm{E}-05$ & $<5.36 \mathrm{E}-05$ & $<6.43 \mathrm{E}-05$ & $<5.20 \mathrm{E}-05$ & $<5.66 \mathrm{E}-05$ \\
\hline $\mathrm{M}-240(\mathrm{Pu})$ & $<3.17 \mathrm{E}-05$ & $<5.36 \mathrm{E}-05$ & $<3.91 \mathrm{E}-05$ & $<4.15 \mathrm{E}-05$ & $<5.36 \mathrm{E}-05$ & $<6.43 \mathrm{E}-05$ & $<5.20 \mathrm{E}-05$ & $<5.66$ E-05 \\
\hline M-241 (Pu,Am) & $<3.17 \mathrm{E}-05$ & $<5.36 \mathrm{E}-05$ & $<3.91 \mathrm{E}-05$ & $<4.15 \mathrm{E}-05$ & $<5.36$ E-05 & $<6.43 \mathrm{E}-05$ & $<5.20$ E-05 & $<5.66 \mathrm{E}-05$ \\
\hline M-242 (Pu) & $<3.17 \mathrm{E}-05$ & $<5.36$ E-05 & $<3.91 \mathrm{E}-05$ & $<4.15 \mathrm{E}-05$ & $<5.36$ E-05 & $<6.43 \mathrm{E}-05$ & $<5.20$ E-05 & $<5.66$ E-05 \\
\hline M-243 (Am,Cm) & $<3.17 \mathrm{E}-05$ & $<5.36 \mathrm{E}-05$ & $<3.91 \mathrm{E}-05$ & $<4.15 \mathrm{E}-05$ & $<5.36 \mathrm{E}-05$ & $<6.43 \mathrm{E}-05$ & $<5.20 \mathrm{E}-05$ & $<5.66$ E-05 \\
\hline M-244 (Pu,Cm) & $<3.17 \mathrm{E}-05$ & $<5.36 \mathrm{E}-05$ & $<3.91 \mathrm{E}-05$ & $<4.15 \mathrm{E}-05$ & $<5.36 \mathrm{E}-05$ & $<6.43 \mathrm{E}-05$ & $<5.20 \mathrm{E}-05$ & $<5.66$ E-05 \\
\hline M-245 (Cm) & $<3.17 \mathrm{E}-05$ & $<5.36$ E-05 & $<3.91 \mathrm{E}-05$ & $<4.15 \mathrm{E}-05$ & $<5.36 \mathrm{E}-05$ & $<6.43 \mathrm{E}-05$ & $<5.20$ E-05 & $<5.66 \mathrm{E}-05$ \\
\hline M-246 (Cm) & $<3.17 \mathrm{E}-05$ & $<5.36 \mathrm{E}-05$ & $<3.91 \mathrm{E}-05$ & $<4.15 \mathrm{E}-05$ & $<5.36 \mathrm{E}-05$ & $<6.43 \mathrm{E}-05$ & $<5.20 \mathrm{E}-05$ & $<5.66$ E-05 \\
\hline M-247 (Cm,Bk) & $<3.17 \mathrm{E}-05$ & $<5.36 \mathrm{E}-05$ & $<3.91 \mathrm{E}-05$ & $<4.15 \mathrm{E}-05$ & $<5.36 \mathrm{E}-05$ & $<6.43 \mathrm{E}-05$ & $<5.20 \mathrm{E}-05$ & $<5.66 \mathrm{E}-05$ \\
\hline \multicolumn{9}{|c|}{$P u-238 / 241$} \\
\hline $\begin{array}{l}{ }^{239} \mathrm{Pu} \mathrm{\&}{ }^{240} \mathrm{Pu} \\
\text { (dpm/mL) }\end{array}$ & 2.57E+03 & $5.89 \mathrm{E}+04$ & $<2.16 \mathrm{E}+03$ & $2.12 E+04$ & $1.08 \mathrm{E}+04$ & $2.38 \mathrm{E}+04$ & $2.59 \mathrm{E}+04$ & $2.02 E+04$ \\
\hline${ }^{238} \mathrm{Pu}$ (wt. \%) & 1.12E-06 & 7.71E-07 & 8.52E-07 & 9.14E-07 & 1.14E-06 & $9.18 \mathrm{E}-07$ & 7.92E-07 & 9.52E-07 \\
\hline${ }^{241} \mathrm{Pu}$ (wt. \%) & 6.30E-08 & $1.18 \mathrm{E}-07$ & 8.62E-08 & 8.89E-08 & 5.34E-08 & 4.55E-08 & $5.90 \mathrm{E}-08$ & $5.26 \mathrm{E}-08$ \\
\hline \multicolumn{9}{|c|}{ Actinides Summary (wt. \%) } \\
\hline Total U & $1.20 \mathrm{E}-03$ & $9.66 \mathrm{E}-04$ & $9.58 \mathrm{E}-04$ & $1.04 \mathrm{E}-03$ & $1.04 \mathrm{E}-03$ & $1.88 \mathrm{E}-03$ & $9.08 \mathrm{E}-04$ & $1.28 \mathrm{E}-03$ \\
\hline Total Pu & 1.18E-06 & 8.89E-07 & 9.39E-07 & 1.00E-06 & $1.20 \mathrm{E}-06$ & 9.64E-07 & 8.51E-07 & 1.00E-06 \\
\hline \multicolumn{9}{|c|}{ Enrichment (mass fraction) } \\
\hline$\overline{235} \mathrm{U} /$ Tot.U & 0.116 & 0.106 & 0.098 & 0.107 & 0.115 & 0.047 & 0.142 & 0.101 \\
\hline
\end{tabular}


Table 7: TK-41-HTF-E-173 dry insoluble solids ICP-ES results.

\begin{tabular}{|c|c|c|c|c|c|c|}
\hline & \multicolumn{3}{|c|}{ Aqua Regia Dissolution } & \multicolumn{3}{|c|}{ Peroxide Fusion Digestion } \\
\hline Species/Analysis & 1 & 2 & Average & 1 & 2 & Average \\
\hline \multicolumn{7}{|c|}{ ICP-ES (wt. \%) } \\
\hline $\mathrm{Ag}$ & $<9.20 \mathrm{E}-03$ & 1.43E-02 & $1.18 \mathrm{E}-02$ & $\mathrm{~N} / \mathrm{A}$ & $\mathrm{N} / \mathrm{A}$ & N/A \\
\hline $\mathrm{Al}$ & $2.79 \mathrm{E}+01$ & $3.01 \mathrm{E}+01$ & $2.90 \mathrm{E}+01$ & $2.93 \mathrm{E}+01$ & $3.11 \mathrm{E}+01$ & $3.02 \mathrm{E}+01$ \\
\hline $\mathrm{B}$ & $<3.22 \mathrm{E}-02$ & $<4.91 \mathrm{E}-02$ & $<4.07 \mathrm{E}-02$ & $<4.06 \mathrm{E}-02$ & $<3.59 \mathrm{E}-02$ & $<3.83 \mathrm{E}-02$ \\
\hline $\mathrm{Ba}$ & 3.87E-02 & 4.06E-02 & 3.97E-02 & 4.65E-02 & $<2.44 \mathrm{E}-02$ & 3.55E-02 \\
\hline $\mathrm{Ca}$ & $6.33 \mathrm{E}-01$ & 6.49E-01 & 6.41E-01 & 9.83E-01 & $6.70 \mathrm{E}-01$ & 8.27E-01 \\
\hline $\mathrm{Cd}$ & $<4.83 \mathrm{E}-03$ & $<7.37 \mathrm{E}-03$ & $<6.10 \mathrm{E}-03$ & $<6.09 \mathrm{E}-03$ & $<5.38 \mathrm{E}-03$ & $<5.74 \mathrm{E}-03$ \\
\hline $\mathrm{Ce}$ & $<3.10 \mathrm{E}-02$ & $<4.74 \mathrm{E}-02$ & $<3.92 \mathrm{E}-02$ & n.d. & n.d. & n.d. \\
\hline $\mathrm{Cr}$ & $1.47 \mathrm{E}+00$ & $1.44 \mathrm{E}+00$ & $1.46 \mathrm{E}+00$ & $1.08 \mathrm{E}+00$ & 5.59E-01 & 8.20E-01 \\
\hline $\mathrm{Cu}$ & $1.58 \mathrm{E}-01$ & $6.25 \mathrm{E}-02$ & 1.10E-01 & 5.35E-02 & 3.63E-02 & 4.49E-02 \\
\hline $\mathrm{Fe}$ & $5.08 \mathrm{E}+00$ & $2.91 \mathrm{E}+00$ & $4.00 \mathrm{E}+00$ & $2.07 \mathrm{E}+00$ & $1.07 \mathrm{E}+00$ & $1.57 \mathrm{E}+00$ \\
\hline $\mathrm{Gd}$ & $<2.69 \mathrm{E}-02$ & $<4.11 \mathrm{E}-02$ & $<3.40 \mathrm{E}-02$ & $4.50 \mathrm{E}-02$ & $<3.00$ E-02 & 3.75E-02 \\
\hline $\mathrm{K}$ & $<1.08 \mathrm{E}+00$ & $<1.65 \mathrm{E}+00$ & $<1.37 \mathrm{E}+00$ & $<1.36 \mathrm{E}+00$ & $<1.20 \mathrm{E}+00$ & $<1.28 \mathrm{E}+00$ \\
\hline $\mathrm{La}$ & $<8.28 \mathrm{E}-03$ & $<1.26 \mathrm{E}-02$ & $<1.04 \mathrm{E}-02$ & $1.85 \mathrm{E}-02$ & $<9.23 \mathrm{E}-03$ & 1.39E-02 \\
\hline $\mathrm{Li}$ & $<4.94 \mathrm{E}-02$ & $<7.54 \mathrm{E}-02$ & $<6.24 \mathrm{E}-02$ & $<6.23 \mathrm{E}-02$ & $<5.51 \mathrm{E}-02$ & $<5.87 \mathrm{E}-02$ \\
\hline $\mathrm{Mg}$ & $1.38 \mathrm{E}-02$ & $<9.30 \mathrm{E}-03$ & 1.16E-02 & $<7.68 \mathrm{E}-03$ & $<6.79 \mathrm{E}-03$ & $<7.24 \mathrm{E}-03$ \\
\hline $\mathrm{Mn}$ & $1.61 \mathrm{E}-01$ & $1.22 \mathrm{E}-01$ & 1.42E-01 & 9.73E-02 & 5.10E-02 & 7.42E-02 \\
\hline Mo & $<6.09 \mathrm{E}-02$ & $<9.30 \mathrm{E}-02$ & $<7.70$ E-02 & 7.96E-02 & $<6.79 \mathrm{E}-02$ & 7.38E-02 \\
\hline $\mathrm{Na}$ & 7.06E-01 & 7.34E-01 & 7.20E-01 & $\mathrm{N} / \mathrm{A}$ & $\mathrm{N} / \mathrm{A}$ & N/A \\
\hline $\mathrm{Ni}$ & 9.38E-02 & 9.75E-02 & 9.57E-02 & 6.88E-02 & 3.98E-02 & 5.43E-02 \\
\hline $\mathrm{P}$ & $<7.93 \mathrm{E}-02$ & $<1.21 \mathrm{E}-01$ & $<1.00 \mathrm{E}-01$ & $<1.00 \mathrm{E}-01$ & $<8.85 \mathrm{E}-02$ & $<9.43 \mathrm{E}-02$ \\
\hline $\mathrm{Pb}$ & $<3.67 \mathrm{E}-02$ & $<5.60 \mathrm{E}-02$ & $<4.64 \mathrm{E}-02$ & $<4.62 \mathrm{E}-02$ & $<4.09 \mathrm{E}-02$ & $<4.36 \mathrm{E}-02$ \\
\hline $\mathrm{Si}$ & $\mathrm{N} / \mathrm{A}$ & $\mathrm{N} / \mathrm{A}$ & N/A & 4.67E-01 & $3.58 \mathrm{E}-01$ & 4.13E-01 \\
\hline $\mathrm{Sn}$ & $<5.17 \mathrm{E}-02$ & $<7.89 \mathrm{E}-02$ & $<6.53 \mathrm{E}-02$ & $1.21 \mathrm{E}-01$ & $<5.77 \mathrm{E}-02$ & 8.94E-02 \\
\hline $\mathrm{Sr}$ & $1.08 \mathrm{E}-01$ & $1.08 \mathrm{E}-01$ & 1.08E-01 & 1.94E-01 & 1.33E-01 & 1.64E-01 \\
\hline $\mathrm{Ti}$ & $<8.85 \mathrm{E}-03$ & $<1.35 \mathrm{E}-02$ & $<1.12 \mathrm{E}-02$ & $1.58 \mathrm{E}-02$ & $<9.87 \mathrm{E}-03$ & $1.28 \mathrm{E}-02$ \\
\hline $\mathrm{Zn}$ & 7.35E-02 & $1.01 \mathrm{E}-01$ & 8.73E-02 & $\mathrm{N} / \mathrm{A}$ & $\mathrm{N} / \mathrm{A}$ & N/A \\
\hline $\mathrm{Zr}$ & $<2.62 \mathrm{E}-02$ & $<4.00 \mathrm{E}-02$ & $<3.31 \mathrm{E}-02$ & $\mathrm{~N} / \mathrm{A}$ & $\mathrm{N} / \mathrm{A}$ & N/A \\
\hline
\end{tabular}


Table 8: TK-41-HTF-E-173 dry insoluble solids actinides results.

\begin{tabular}{|c|c|c|c|c|c|c|}
\hline & \multicolumn{3}{|c|}{ Aqua Regia Dissolution } & \multicolumn{3}{|c|}{ Peroxide Fusion Digestion } \\
\hline Species/Analysis & 1 & 2 & Average & 1 & 2 & Average \\
\hline \multicolumn{7}{|c|}{ ICP-MS (wt. \%) } \\
\hline M-230 (Th) & $<1.09 \mathrm{E}-04$ & $<1.67 \mathrm{E}-04$ & $<1.38 \mathrm{E}-04$ & $<3.48 \mathrm{E}-04$ & $<3.08 \mathrm{E}-04$ & $<3.28 \mathrm{E}-04$ \\
\hline $\mathrm{M}-231(\mathrm{~Pa})$ & $<1.09 \mathrm{E}-04$ & $<1.67 \mathrm{E}-04$ & $<1.38 \mathrm{E}-04$ & $<3.48 \mathrm{E}-04$ & $<3.08 \mathrm{E}-04$ & $<3.28 \mathrm{E}-04$ \\
\hline $\mathrm{M}-232(\mathrm{Th}, \mathrm{U})$ & 1.97E-03 & $1.61 \mathrm{E}-03$ & 1.79E-03 & $<3.48 \mathrm{E}-04$ & $<3.08 \mathrm{E}-04$ & $<3.28 \mathrm{E}-04$ \\
\hline $\mathrm{M}-233(\mathrm{U})$ & $1.52 \mathrm{E}-03$ & $1.61 \mathrm{E}-03$ & 1.57E-03 & $1.59 \mathrm{E}-03$ & $6.58 \mathrm{E}-04$ & 1.13E-03 \\
\hline $\mathrm{M}-234(\mathrm{U})$ & $9.14 \mathrm{E}-03$ & 9.37E-03 & $9.25 \mathrm{E}-03$ & $7.16 \mathrm{E}-03$ & $3.53 E-03$ & 5.34E-03 \\
\hline M-235 (U) & 2.69E-02 & $2.77 \mathrm{E}-02$ & 2.73E-02 & $2.18 \mathrm{E}-02$ & 1.03E-02 & 1.61E-02 \\
\hline $\mathrm{M}-236(\mathrm{U})$ & $9.68 \mathrm{E}-03$ & 9.71E-03 & 9.70E-03 & 8.54E-03 & 3.87E-03 & 6.21E-03 \\
\hline M-237 (Np) & 8.09E-03 & 7.98E-03 & 8.03E-03 & 6.57E-03 & $3.14 \mathrm{E}-03$ & 4.86E-03 \\
\hline $\mathrm{M}-238(\mathrm{U}, \mathrm{Pu})$ & $1.63 \mathrm{E}-01$ & $1.70 \mathrm{E}-01$ & 1.66E-01 & $1.41 \mathrm{E}-01$ & $6.27 \mathrm{E}-02$ & $1.02 \mathrm{E}-01$ \\
\hline $\mathrm{M}-239(\mathrm{Pu})$ & $3.35 \mathrm{E}-04$ & $<1.67 \mathrm{E}-04$ & $2.51 \mathrm{E}-04$ & $1.15 \mathrm{E}-03$ & $<3.08 \mathrm{E}-04$ & $7.30 \mathrm{E}-04$ \\
\hline $\mathrm{M}-240(\mathrm{Pu})$ & $<1.09 \mathrm{E}-04$ & $<1.67 \mathrm{E}-04$ & $<1.38 \mathrm{E}-04$ & $<3.48 \mathrm{E}-04$ & $<3.08 \mathrm{E}-04$ & $<3.28 \mathrm{E}-04$ \\
\hline $\mathrm{M}-241(\mathrm{Pu}, \mathrm{Am})$ & $<1.09 \mathrm{E}-04$ & $<1.67 \mathrm{E}-04$ & $<1.38 \mathrm{E}-04$ & $<3.48 \mathrm{E}-04$ & $<3.08 \mathrm{E}-04$ & $<3.28 \mathrm{E}-04$ \\
\hline $\mathrm{M}-242(\mathrm{Pu})$ & $<1.09 \mathrm{E}-04$ & $<1.67 \mathrm{E}-04$ & $<1.38 \mathrm{E}-04$ & $<3.48 \mathrm{E}-04$ & $<3.08 \mathrm{E}-04$ & $<3.28 \mathrm{E}-04$ \\
\hline $\mathrm{M}-243(\mathrm{Am}, \mathrm{Cm})$ & $<1.09 \mathrm{E}-04$ & $<1.67 \mathrm{E}-04$ & $<1.38 \mathrm{E}-04$ & $<3.48 \mathrm{E}-04$ & $<3.08 \mathrm{E}-04$ & $<3.28 \mathrm{E}-04$ \\
\hline $\mathrm{M}-244(\mathrm{Pu}, \mathrm{Cm})$ & $<1.09 \mathrm{E}-04$ & $<1.67 \mathrm{E}-04$ & $<1.38 \mathrm{E}-04$ & $<3.48 \mathrm{E}-04$ & $<3.08 \mathrm{E}-04$ & $<3.28 \mathrm{E}-04$ \\
\hline $\mathrm{M}-245(\mathrm{Cm})$ & $<1.09 \mathrm{E}-04$ & $<1.67 \mathrm{E}-04$ & $<1.38 \mathrm{E}-04$ & $<3.48 \mathrm{E}-04$ & $<3.08 \mathrm{E}-04$ & $<3.28 \mathrm{E}-04$ \\
\hline M-246 (Cm) & $<1.09 \mathrm{E}-04$ & $<1.67 \mathrm{E}-04$ & $<1.38 \mathrm{E}-04$ & $<3.48 \mathrm{E}-04$ & $<3.08 \mathrm{E}-04$ & $<3.28 \mathrm{E}-04$ \\
\hline $\mathrm{M}-247(\mathrm{Cm}, \mathrm{Bk})$ & $<1.09 \mathrm{E}-04$ & $<1.67 \mathrm{E}-04$ & $<1.38 \mathrm{E}-04$ & $<3.48 \mathrm{E}-04$ & $<3.08 \mathrm{E}-04$ & $<3.28 \mathrm{E}-04$ \\
\hline \multicolumn{7}{|c|}{$P u-238 / 241$} \\
\hline $\begin{array}{l}{ }^{239} \mathrm{Pu} \&{ }^{240} \mathrm{Pu} \\
\text { (dpm/mL) }\end{array}$ & $1.94 \mathrm{E}+05$ & $1.02 \mathrm{E}+06$ & $6.07 \mathrm{E}+05$ & $1.42 \mathrm{E}+06$ & $1.07 E+05$ & $7.64 \mathrm{E}+05$ \\
\hline${ }^{238} \mathrm{Pu}$ (wt. \%) & 2.63E-04 & 2.66E-04 & 2.64E-04 & 2.07E-04 & $8.18 E-05$ & 1.45E-04 \\
\hline${ }^{241} \mathrm{Pu}$ (wt. \%) & $1.21 \mathrm{E}-06$ & $1.03 E-06$ & $1.12 \mathrm{E}-06$ & $1.96 \mathrm{E}-06$ & $3.74 \mathrm{E}-07$ & 1.17E-06 \\
\hline \multicolumn{7}{|c|}{ Actinides Summary (wt. \%) } \\
\hline Total U & $2.10 \mathrm{E}-01$ & $2.18 \mathrm{E}-01$ & 2.14E-01 & $1.80 \mathrm{E}-01$ & 8.11E-02 & 1.31E-01 \\
\hline Total Pu & 5.99E-04 & $2.67 E-04$ & 4.33E-04 & 1.36E-03 & 3.90E-04 & 8.76E-04 \\
\hline \multicolumn{7}{|c|}{ Enrichment (mass fraction) } \\
\hline${ }^{235} \mathrm{U} /$ Tot.U & 0.128 & 0.127 & 0.128 & 0.121 & 0.127 & 0.124 \\
\hline
\end{tabular}

